\title{
Analysis of Capital Relationships and Financial Statement Disclosures on the Net Profit Margin of Insurance Companies
}

\author{
Dian Efriyenty \\ Universitas Putera Batam, Indonesia \\ Dian.Efriyenti@puterabatam.ac.id
}

\begin{abstract}
The survey results on disclosure of financial statements, there were managers who did not disclose their intangible assets. Judging from the development of financial accounting standards No. 19 which states that not many companies have disclosed it. The phenomenon develops along with these standards. The research objective is to assess the intellectuals of this standard. The purpose of this study is to analyze capital relations and disclosure of financial statements on the margin on net income. The objects of this research are eleven insurance business units. Collecting data from reference books and journals as well as financial statement. Analysis of the data used with the help of partial tests and concurrent testing. Based on the processed data, relationship capital has no impact on margins. Meanwhile, disclosure of financial statements has an impact on net income. And the results together have an effect on the margins on net income.
\end{abstract}

Keywords: Relational Capital, Disclosure of Financial Statements, Net Profit Margin

\section{Pendahuluan}

Perusahaan asuransi Tbk perusahaan yang memiliki peran strategis untuk perekonomian (Fahmi \& Irham, 2016, p. 12). Tetapi pertumbuhan perusahaan asuransi ini tidak menjamin banyak yang terjun pada intellectual capital disclosure khususnya di laporan keuangan.

Berdasarkan data laporan (Otoritas, 2018) dapat diketahui net profit margin Asuransi Harta Aman Pratama Tbk periode 2016 sebesar 0,14\%, meningkat 0,073\% pada periode 2018 menjadi $0,067 \%$. Asuransi Multi Artha Guna Tbk periode 2016 sebesar 0,14\%, menurun 0,06\% periode 2018 menjadi 0,08\%. Asuransi Bintang Tbk periode 2016 sebesar 0,08\% menurun 0,05\% kemudian turun Kembali di tahun 2018 menjadi 9,03\% (Bursa Efek, 2018). Maka industri dalam usaha pengembangan bisnis akan terus meningkat dengan adanya inovasi memperhatikan sumber daya manusia. Jika semakin turun nilai modal intellectual manusia sebuah perusahaan asuransi, maka perusahaan asuransi akan menyajikan asset tidak berwujudnya (Rachmawati, 2017)

Berdasarkan hasil survey dilapangan pentingnya memperhatikan strategis bisnis yang tidak berwujud, antara lain pengembangan teknologi,merek dagang berdasarkan pedoman pernyataan standar akuntansi (PSAK) No. 02 Tahun 2000 dapat mengakibatkan knowledge based business. Berdasarkan hasil research (Rachmawati, 2017) sebuah perushaan semakin baik intellectual capitalnya, maka semakin baik juga pengembalian aktivanya (Dwipayani \& Chandar, 2017).

Intellectual capital disclosure tidak berdampak pada kinerja keuangan (Safitri, 2017). Hal ini terbukti bahwa Indonesia tidak hanya menggunakan modal fisik untuk menilai financial performance (Boujelbene et al., 2017).

Berdasarkan survey dari pedoman PSAK No 19 (Revisi 2017) terkait pengungkapan modal intellectual yang dilakukan oleh unit usaha bersifat voluntary (Melani \& Suwarni, 2018). Namun ada beberapa manager tidak ingin mengungkapkan modal intellectual secara keseluruhan, sehingga mengetahui kelebihan unit usaha (Faradina, 2018).

Berdasarkan fenomena awal yang telah dijelaskan dan isu permasalahan yang didapat, research ini terkait "Analisa Relational Capital dan Intellectual Capital Disclosure Terhadap Net Profit Margin Pada Perusahaan Asuransi". 


\section{Tinjauan Literatur}

\section{Rasio Margin Laba Bersih}

Margin laba bersih ialah kemampuan dalam mengukur laba setelah dipotong dengan pajak dengan penjualan bersih yang dihasilkan perusahaan (Kasmir, 2018, p. 67).

Rasio ini dihitung dengan rumus:

\section{Pengertian Intellectual Capital}

Modal intelektual merupakan suatu tahap yang dipunyai oleh staf ialah suatu aktiva berupa ilmu pengetahuan, suatu proses bisnis, pengembangan kegiatan bisnis maupun reward dari hasil kinerja (Sangkala, 2017, p. 17). Modal yang dimiliki oleh unit usaha dalam bentuk kemampuan staf dalam menghadapi persaingan global (Bontis et al., 2018).

\section{Komponen Intellectual Capital}

Komponen modal intelektual terbagi menjadi 3 komponen besar (Sangkala, 2017, p. 51) diantaranya:

a. Structural Capital atau Internal Capital

Modal structural sebagai meningkatnya produktif staf. Diantaranya organization, tahap proses, budaya organisasi yang baik untuk civitas unit usaha (Ulum, 2017).

b. Customer Capital atau Relational Capital

Modal relasi memaparkan terkaitt dengan unit usaha satu dengan yang lain diantaranya phak relasi konsumen, masyarakat maupun pemerintah yang terjalin (Ulum, 2017).

c. Modal Manusia

Modal manusia ialah staf unit usaha yang memiliki keunggulan serta ide-ide untuk pengembangan di unit usaha dalam persaingan pasar (Ulum, 2017).

Modal intelektual : Biaya staf ialah dengan mengukurnya melalui reward maupun education yang telah diikuti oleh staf (Bontis et al., 2018).

\section{Pengertian Intellectual Capital Disclosure}

Pengungkapan modal intelektual ialah pernyataan-pernyataan berkaitan dengan pernyataan strategi staf, pemaparan dengan cukup dan lengkap (Suhardjanto \& Wardhani, 2017).

\section{Pengukuran Intellectual Capital Disclosure}

Pengelompokkan pengungkapan modal intelektual terdiri dari 36 item dengan skor kumulatif (Aprisa, 2016).

\section{Penelitian Terdahulu}

Hasil research sebelumnya diantaranya :

(Gregorio \& Castro, 2017) modal intelektual dari berbagai prospek. Pandangan berbasis modal intelektual dari perusahaan, sebagian besar masalah ini berkaitan dengan konseptualisasi dan tipologi IC, pengukurannya dan keterbatasan masalah yang paling banyak serta beberapa arah yang mungkin untuk pengembangan di masa depan.

(Francisca Tejedo Romero, 2018) Management strategy and intellectual capital disclosure: influence of corporate governance, This discrepancy has been one of the main reasons companies voluntarily manage and disclose them. 
(Yong Quan, Lia Chih Hsin, \& Sam Liu, 2018) Peran identifikasi masalah intelektual dalam pengelolaan keuangan kompetitif Hotel, Hasil penelitian ini mendukung model struktural di mana oleh efek tidak langsung dari modal intelektual pada keunggulan kompetitif hotel ditentukan melalui mekanisme identifikasi masalah.

(Aino et al., 2018) Praktek manajemen sumber daya berbasis pengetahuan dan inovasi, menyatakan memediasi secara positif hubungan antara praktik sumber daya manusia berbasis pengetahuan dan kinerja inovasi dan menggambarkan peran penting modal intelektual.

\section{Model Penelitian}

Berdasarkan landasan teori, model researchnya adalah:

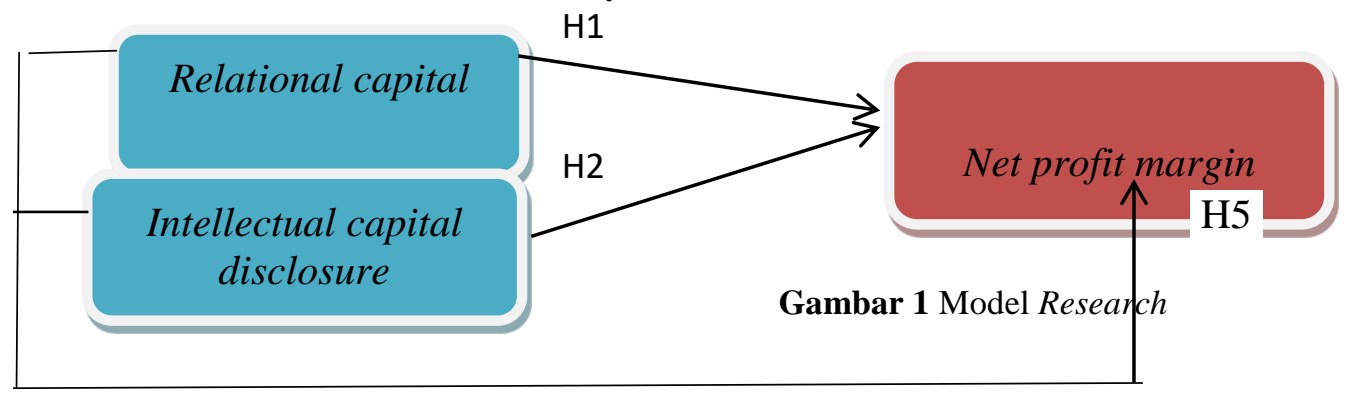

\section{Hipotesis Penelitian}

Adapun hipotesis yang dijabarkan dibawah ini :

1. Relational capital berpengaruh positif terhadap margin atas laba bersih pada unit usaha asuransi

2. Pengungkapan modal intelektual berpengaruh signifikan terhadap margin atas laba bersih unit usaha asuransi

3. Modal relasi secara bersama-sama terhadap margin atas laba bersih pada unit usaha asuransi.

\section{Metodologi Penelitian}

\section{Metode Research}

Metode research ini dengan mengumpulkan data keuangan jumlah perusahaan asuransi.

\section{Populasi dan Sampel}

Objek populasi dipilih semua perusahaan asuransi pada tahun 2014-2019 terdiri dari 14 perusahaan. Berikut ditampilkan perusahaan asuransinya:

Adapun kreteria pemilihan sampel yang ditetapkan sebagai berikut:

1. Register di BEI

2. Saham Non Syariah

3. Laporan keuangan lengkap menyajikan berakhir 31 Desember

4. Memiliki kelengkapan data penelitian

Jadi dari jumlah populasi 14 Perusahaan, peneliti mengambil jumlah sampel sebanyak 11 perusahaan yang memenuhi ditetapkan diatas. 


\section{Teknik Pengumpulan Data}

Tahap pengkoleksian data menggunakan referensi buku dan jurnal serta data laporan keuangan.

\section{Instrumen Pengumpulan Data}

Instrument yang akan digunakan data keuangan unit usaha asuransi, dokumentasi terkait data unit usaha asuransi

\section{Metode Analisa}

Proses Analisa yang digunakan ialah menggunakan uji t dan uji bersama (uji f).

\section{Hasil dan Pembahasan}

\section{Research Result}

Research yang dipakai menganalisis modal relasi dan intelektual capital disclosure dengan dampaknya pada margin laba bersih.

Tabel 1 Deskriptif

\begin{tabular}{|l|r|r|r|r|r|}
\hline & \multicolumn{1}{|c|}{ Jumlah } & \multicolumn{1}{c|}{ Min } & \multicolumn{1}{c|}{ Max } & \multicolumn{1}{c|}{ Mean } & \multicolumn{1}{c|}{ Deviation } \\
\hline X1_RelationalCapital & 55 & .00 & 89.00 & 19.9000 & 29.41822 \\
X2_Intellectualcapitaldis & 55 & 6000.00 & 8760.00 & 9000.2000 & 1960.7274 \\
closure & 55 & -19.00 & 150.00 & 29.0182 & 7.3265 \\
Y_Netprofitmargin & 55 & & & & \\
\hline
\end{tabular}

Sumber: Data diolah, SPSS 25, 2020

Dalam tabel 1 diatas terlihat bahwa Relational Capital dan Intellectual Capital Disclosure Terhadap Net Profit Margin. Margin laba bersih ini ialah keuntungan suatu usaha dalam mengelola pendapatan. Dengan nilai rata-rata 7,3265. Nilai minimum $-19,00$ dan nilai maksimum 150,00 begitu halnya untuk standar deviasi 7,3265.

Relational Capital ialah suatu hubungan dengan pihak-pihak eksternal yang dibutuhkan demi menunjang kegiatan usaha. Pada table 1 diatas nilai minimum sebesar 0,00 dan maksimum 89,00, serta standar deviasi 29,41.

Intellectual Capital Disclosure ialah keterbukaan informasi keuangan terkait dengan internal usaha seperti jumlah karyawan, research, teknologi dll. Pada tabel 1 dapat dikatakan bahawa nilai minimum 6,000 dan nilai maksimum 8760,00, serta deviasi 1960,72.

\section{Uji Hipotesis}

\section{Hasil Uji t}

Dimanfaarkan untuk melihat analisa variabel bebas terhadap variabel terikat.

Tabel 2 Hasil Uji t

\begin{tabular}{|l|r|r|r|r|r|}
\hline & \multicolumn{2}{|c|}{ Unstandardized } & \multicolumn{1}{c|}{ Standardized } & \multicolumn{1}{c|}{ t } & \multicolumn{1}{c|}{ Sig. } \\
\cline { 2 - 6 } & \multicolumn{1}{c|}{ B } & \multicolumn{1}{c|}{ Error } & \multicolumn{1}{c|}{ Beta } & & \\
\hline & 33.589 & 19.1890 & & 1.976 & .097 \\
\hline X1_RelationalCapital & .176 & .199 & .167 & 1.673 & .372 \\
\hline $\begin{array}{l}\text { X2_Intellectualcapital } \\
\text { disclosure }\end{array}$ & .008 & .007 & .530 & 2.034 & .000 \\
\hline
\end{tabular}

Sumber : Data diolah, SPSS 25, 2020 
Dari data diatas dapat dikatakan semua variabel independent berpengaruh signifikan terhadap margin laba bersih yaitu modal relasional serta pengungkapan modal keuangan dengan signifikan dibawah 0,05 .

\section{Hasil Uji Bersamaan}

Adapun hasil olahan data melalui secara bersama-sama.

Tabel 3 Pengujian Bersamaan

\begin{tabular}{|l|l|r|r|r|r|r|}
\hline \multicolumn{2}{|c|}{} & $\begin{array}{c}\text { Sum of } \\
\text { Squares }\end{array}$ & Df & Square & F & Sig. \\
\hline \multirow{3}{*}{} & Regression & 38093.216 & 4 & 9523.304 & 26.009 & $.001^{\mathrm{b}}$ \\
\cline { 2 - 7 } & & 22665.766 & 50 & 453.315 & & \\
\cline { 2 - 7 } & Total & 60758.982 & 54 & & & \\
\hline
\end{tabular}

Sumber : Olahan, SPSS 25, 2020

Dapat dikatakan diatas maka dapat dikatakan signfikan 0,001, maka secara bersamasama modal relasi dan pengungkapan modal keuangan terhadap margin laba bersih.

\section{Hasil Uji Determinan}

Uji ini (Chandrarin, 2017: 141), ialah untuk memprediksi dari hasil research yang mempengaruh terhadap faktor terikat.

Tabel 4 Uji Determinan

\begin{tabular}{|l|l|l|l|}
\hline $\mathrm{R}$ & R Square & $\begin{array}{l}\text { Adjusted R } \\
\text { Square }\end{array}$ & Estimate \\
\hline $.899^{\mathrm{a}}$ & .852 & .670 & 39.9834 \\
\hline
\end{tabular}

Sumber : Data diolah, SPSS 25, 2020

Dengan data diatas $\mathrm{R}^{2}$ memiliki nilai 0,852 atau $85,2 \%$ sedangkan sisanya tidak dteliti dalam penelitian ini.

\section{Pembahasan}

Adapun ringkasan dalam penelitian ini berdampak terhadap margin laba bersih.

Modal Relasi Berpengaruh Terhadap Margin Laba Bersih Pada Perusahaan Asuransi

Hasil olahan signifikan $0,372>0,05$. Modal relasi lebih mudah integrasi meningkatkan kemampuan inovasi dan praktik, hasil ini mendukung research (Saragih, 2017) menyatakan margin laba bersih berdampak pada modal relasi. Integritas proses, membangun ide praktek pengembangan inovasi unit usaha merupakan dasar yang penting. Research (Saragih, 2017) modal relasi berdampak pada margin laba bersih.

Pengungkapan Laporan Keuangan Berpengaruh Terhadap Margin Atas Laba Bersih Pada Perusahaan Asuransi

Hasil research dibawah 0,05 , sehingga hipotesa kelima diterima. Hasil olahan data signifikanya 0,000 lebih kecil 0,05. Sehingga hipotesa kedua diterima. Salah satu bentu pengungkapan laporan keuangan yang masih banyak belum digunakan oleh organisasi diantaranya terkait ilmu pengetahuan karyawan, hubungan pelanggan serta value unit usaha. Research (Pratiwi \& Sudarso, 2018) modal intelektual, modal relasi dan nilai tambah structural memiliki dampak pada margin atas laba bersih.

Modal Relasi dan Intellectual Capital Disclosure Berdampak Terhadap Margin Atas Laba Bersih 
Berdasarkan hasil olahan bahwa secara bersama-sama value $0,001<0,05$. Sehingga hipotesa ketiga diterima. Perluasan asimetri informasi antara pemilik dan calon investor untuk dapat meningkatkan value dalam jangka Panjang.

Research (Febrianty \& Febriantoko, 2018) mengatakan kinerja laporan keuangan akan memiliki dampak kepada modal intelektual pada perusahaan.

\section{Kesimpulan}

Intisari research dalam penelitian ini, diantaranya:

1. Modal relasi nilai sig dibawah 0,372 diatas 0,05 maka hipotesa pertama ditidak diterima.

2. Pengungkapan laporan keuangan memiliki nilai 0,000 lebih kecil 0,05, sehingga hipotesa kedua diterima.

3. Modal relasi dan pengungkapan modal intelektual secara bersama-sama nilai signifikan 0,001 lebih kecil 0,05. Maka hipotesa ketiga diterima.

\section{Daftar Isi}

[1] Aino, K., Paavo, R., Mika, V., \& Henri, H. (2018). Reflections on the criteria for the sound Measurement of intellectual capital: A knowledge-based perspective. Critical Perspectives on Accounting, 7(3), 112- 118. https://doi.org/https://doi.org/10.1016/j.cpa.2018.05.002

[2] Bontis, Nick, William, \& Stanley. (2018). Intellectual capital and business performance in malaysian industries. Journal of Intellectual Capital, 1(1), 77-85.

[3] Boujelbene, Ali, M., \& Affes, H. (2017). The impact intellectual capital disclosure on cost of equity capital: a case of french firms. Journal of Economics, Finance and Administrative Science, 18(34), $45-53$.

[4] Dwipayani, \& Chandar, C. (2017). Pengaruh intellectual capital terhadap profitabilitas dan kinerja pasar. Journal American Accounting Association, 4(5), 1-11.

[5] Faradina. (2018). Faktor-faktor yang mempengaruhi pengungkapan intellectual capital pada Perusahaan property dan real estate. Jurnal Bisnis Dan Manajemen, 5(2), 305-326. https://doi.org/http://doi.org/10.4149/av 2010_04 231

[6] Febrianty, \& Febriantoko, J. (2018). Analisis intellectual capital terhadap kinerja keuangan perusahaan industri barang dan konsumsi. Jurnal Akuntansi Dan Pendidikan, 7(1), 45-56.

[7] Francisca Tejedo Romero, J. F. F. E. A. (2018). Management strategy and intellectual capital disclosure: influence of corporate governance. Contaduria y Administracion, 63(2), 1-18. https://doi.org/http://dx.doi.org/10.2201/fca.24488410e.2018.1236

[8] Gregorio, \& Castro, M. de. (2017). Intellectual Capital and the firm: some remaining questions and prospects. Knowledge Management Research \& Practice, 12(3), 239-245. https://doi.org/10.1057/kmrp.2014.13

[9] Kasmir. (2018). Analisis Laporan Keuangan (Edisi 1, C). RajaGrafindo Persada.

[10] Otoritas, J. K. (2018). Laporan Keuangan Tahunan Perusahaan Asuransi. Laporan Keuangan Tahunan.

[11] Pratiwi, M. W., \& Sudarso, A. Y. (2018). Analisis Value Added Human Capital, Structural Capital Value Added, Value Added Capital Employed dan Intellectual Capital Disclosure Terhadap Return On Equity dan Net Profit Margin Pada Perusahaan Manufaktur. Journal of Human Capital, 9(5), 110.

[12] Rachmawati. (2017). Pengaruh intellectual capital terhadap return on assets (ROA) perbankan. Journal Akuntansi, 1(1), 19-28 ISSN: 2367-4590.

[13] Safitri. (2017). Intellectual capital and financial performance in microfinance institutions. Juornal of Intellectual Capital, 12(1), 152-164, ISSN: 3467-2876.

[14] Sangkala. (2017). Intellectual capital management-strategi baru membangun daya saing perusahaan. YAPENSI. 
Jurnal EKOBISTEK, Vol.10, No. 2. April 2021, Hal 9-15, ISSN : 2301-5268 | E-ISSN : 2527-9483 Copyright@2021 by LPPM UPI YPTK Padang

[15] Saragih, A. erlina. (2017). Pengaruh intellectual capital terhadap kinerja keuangan perusahaan sub sektor pertambangan. Jurnal Reviu Akuntansi Dan Keuangan, 3(1), 1-24.

[16] Suhardjanto, D., \& Wardhani, M. (2017). Praktik intellectual capital disclosure perusahaan yang terdaftar di bursa efek indonesia. Journal Akuntansi, 14(1), 71-85. https://doi.org/http://doi.org/10.4103/jrms.JRMS_879_17

[17] Ulum. (2017). Intellectual capital: Model pengukuran, framework pengungkapan dan kinerja organisasi. Jurnal Akuntansi, 3(1), 37-46.

[18] Yong Quan, LiaChih Hsin, \& Sam Liu. (2018). The role of problem identification and intellectual capital in the management of hotels competitive advantage-an integrated framework. International $\begin{array}{lllll}\text { Journal of Hospitality } & \text { Management, } & 75(5), & 160-170 .\end{array}$ https://doi.org/https://doi.org/10.1016/j.ijhm.2018.05.022 